TITLE:

\title{
Development of Notch-dependent T-cell leukemia by deregulated Rap1 signaling(Abstract_要旨 )
}

$\operatorname{AUTHOR}(S)$ :

Wang, Shu-Fang

\section{CITATION:}

Wang, Shu-Fang. Development of Notch-dependent T-cell leukemia by deregulated Rap1 signaling. 京都大学, 2008, 博士(生命科学)

\section{ISSUE DATE:}

2008-03-24

URL:

http://hdl.handle.net/2433/137035

RIGHT: 


\begin{tabular}{|c|c|}
\hline 名 & 狅 \\
\hline 学位 (専攻分野) & 博 士 （生命科学） \\
\hline 学 位 記 番 号 & 生 博 第 138 号 \\
\hline 学位授与の日付 & 平成 20 年 3 月 24 日 \\
\hline 学位授与の要件 & 学位規則第 4 条第 1 項該当 \\
\hline 研究科 · 専攻 & 生命科学研究科高次生命科学専攻 \\
\hline 学位論文題目 & Development of Notch-dependent T-cell leukemia by deregulat \\
\hline & ングによるNotch依存性 T細胞白血病の発生) \\
\hline
\end{tabular}

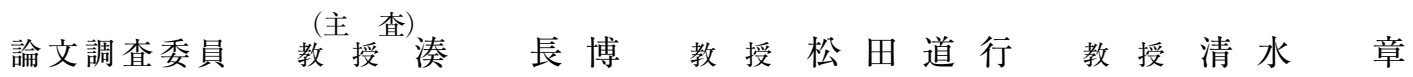

論文内容の要旨

Rap1 (Ras-proximate 1) is a Ras-family G protein mediating diverse functions highly dependent on the contexts of cell types, such as proliferation, differentiation, cell survival, cell adhesion, polarity and movements. Rap1 is activated to Rap1GTP by specific guanine nucleotide exchange factors (GEFs) coupled with diverse receptors, while specific GTPase-activating proteins (GAPs) inactivate Rap1GTP to Rap1GDP. SPA-1 (signal-induced proliferation associated gene-1) functions as a suppressor of myeloid leukemia by negatively regulating Rap1 signaling in hematopoietic progenitor cells (HPC). In the present study, it was shown that transplantation of HPC expressing farnesylated C3G (C3G-F), a Rap1 guanine nucleotide exchange factor, resulted in a marked expansion of thymocytes bearing unique phenotypes, CD4/CD8 double positive (DP) $\mathrm{CD}^{-} \mathrm{TCR} \beta^{-}$, in irradiated recipients. SPA- $1^{-/} \mathrm{HPC}$ expressing $\mathrm{C} 3 \mathrm{G}-\mathrm{F}$ caused a more extensive expansion of DP thymocytes, resulting in lethal T-cell acute lymphoblastic leukemia (T-ALL) with massive invasion of clonal $\mathrm{T}$-cell blasts into vital organs. The $\mathrm{C} 3 \mathrm{G}-\mathrm{F}^{+}$blastic thymocytes exhibited constitutive Rap1 activation and markedly enhanced expression of Notch1, 3 as well as the target genes, Hes1, pT $\alpha$ and $c$-Myc. All the T-ALL cell lines from C3G-F $\mathrm{F}^{+} \mathrm{SPA}-1^{-/-} \mathrm{HPC}$ recipients expressed high levels of Notch1 with characteristic mutations leading to the $\mathrm{C}$-terminal truncation. The proliferation was inhibited completely in the presence of a $\gamma$ secretase inhibitor. Transplantation of Rag2 $2^{-/-} \mathrm{SPA}^{-1 /-} \mathrm{HPC}$ expressing C3G-F also resulted in a marked expansion and transformation of DP thymocytes. The results suggested that deregulated constitutive Rap1 activation caused abnormal expansion of DP thymocytes, bypassing pre-T cell receptor (TCR) and eventually leading to Notch1 mutations and Notch-dependent T-ALL.

\section{論文審査 の 結 果 の 要 旨}

SPA-1はリンパ・造血系組織においてRasスーパファミリーに属する低分子量G蛋白, Rap1の特異的なGTPase活性化蛋 白（GAP）として機能している。SPA-1遺伝子破壊（SPA-1-/-）マウスは，長い潜伏期を経てヒト慢性骨䯣性白血病の慢 性期に酷似した骨髄性増殖疾患や，骨髄異形成症候群あるいはB1細胞白血病など多彩な骨髄性疾患を発症することが報告 されている。これらの白血病発症にRap1が関与することは明らかになっているが，なぜ発症までに長い期間を要するかと いうことについては不明であった。申請者はこの理由としてSPA-1の欠損によりRap1GTP蓄積が起こる過程に長い時間が 必要であるからだという仮説を立て，これを証明するためにRap1活性化因子であるC3Gの常時活性化型分子（C3G-F）を 正常B6およびSPA-1-/ーマウス由来未分化造血細胞（HSC）に導入し，それを放射線照射したレシピエントマウスに移入に その影響について解析を行った。その結果, C3G-Fを導入したB6由来HSCを移植したマウスにおいて移植 3 ヶ月後に $\mathrm{CD} 4 / \mathrm{CD} 8$ 両陽性（DP） CD3/TCR ${ }^{\text {low }}$ という異常な表現系を持つ胸腺細胞の増加が認められた。C3G-Fを導入したSPA-1-/- 
マウス由来HSCを移植した場合, このDP胸腺細胞の増殖はより顕著であり, 移植したマウス全個体が急性Tリンパ芽球性 白血病（T-ALL）により死亡した。この結果から，内在性Rap1の活性化状態と病気の程度が関係していることが確認され た。C3G-F導入発現により増加が見られたSPA-1-/ーマウス由来DP胸腺細胞では, NotchおよびNotch細胞内ドメインの発 現増強が見られるとともに，その增殖が $\gamma$-secretase阻害薬により完全に阻害された。さらにRag2-/-マウスと掛け合わせ たSPA-1-/ーマウス由来HSCにC3G-Fを導入し移植を行った場合もDP胸腺細胞の増殖およびがん化が観察された。この結果 から, Rap1の常時活性化によるDP胸腺細胞の増殖とがん化は, プレT細胞抗原レセプターのシグナルを必要としないこと が示された。以上の結果から, Rap1の常時活性化は, Notchの活性化とそれに続くNotch遺伝子変異の誘導によりT-ALLの 発症をもたらしうることが強く示唆された。

以上の結果は白血病の発症機構の解明に大きく貢献するものであり, 本論文は博士（生命科学）の学位論文として価值の あるものと認めた。なお, 本申請者は平成20年 1 月 21 日に論文内容とそれに関連した口頭試問を受け, 合格と認めたもので ある。 